\title{
Properties of the progestagen-dependent protein of the human endometrium
}

\author{
S. G. Joshi, K. M. Ebert* and R. A. Smith \\ Department of Obstetrics and Gynecology, The Neil Hellman Medical Research Building, \\ Albany Medical College, Albany, New York 12208, U.S.A.
}

\begin{abstract}
Summary. Antigens $A$ and B, shown to be associated with the progestagendominated human endometrium, were partly purified and their properties studied. The antigens were recovered in the crude nuclei, the heavy particulate fraction and cytosol of decidua-rich tissue from early pregnancy. The antigens in cytosol were enriched by a combination of Concanavalin A-Sepharose chromatography and polyacrylamide gel electrophoresis. The immunological reactivity of the antigens after partial purification by Concanavalin A-Sepharose chromatography was retained after 30 min exposure to $4-85^{\circ} \mathrm{C}$ at $\mathrm{pH} 7 \cdot 4$, or after $2 \mathrm{~h}$ to $\mathrm{pH} 2-12$ at $22^{\circ} \mathrm{C}$. Trypsin, but not pepsin, RNase, DNase or neuraminidase, completely destroyed immunological reactivity of both antigens. The apparent molecular weight of both antigens determined by filtration on Sephadex G100 was 48000 . The isoelectric point of both antigens was approximately 4.9. The antigens were not immunologically related to transferrin, ceruloplasmin, alpha-1-antitrypsin, ferritin, uteroglobin, alpha-fetoprotein, human chorionic gonadotrophin, pregnancyassociated plasma proteins or pregnancy zone protein. Furthermore, the antisera to Antigens A and B did not react with the decidual cytosol of pregnant baboons or of pseudopregnant rats.
\end{abstract}

\section{Introduction}

We have previously demonstrated that human endometrial tissues of early pregnancy synthesize two antigens, designated Antigens A and B (Joshi, Ebert, \& Swartz, 1980). The antigens were detected by immunoelectrophoresis and by Ouchterlony's two-dimensional immunodiffusion technique by using antisera raised against the soluble antigens of early pregnancy endometria. These antigens were also detected in the secretory-phase endometria of non-pregnant women, but not in proliferative-phase endometria, sera from pregnant or non-pregnant women or in term placentae. This present paper examines the subcellular distribution, partial purification and properties of Antigens A and B in the human endometrium.

\section{Materials and Methods}

\section{Biological materials}

The following antisera, tissues and body fluids were used in the studies to compare the properties of Antigens A and B with those of known pregnancy-associated proteins.

* Present address: Department of Biology, University of Massachusetts, Amherst, Massachusetts 01002, U.S.A. 
Rabbit antisera to human transferrin, ceruloplasmin, alpha-1-antitrypsin and ferritin were purchased from the Behring Diagnostics, Sommerville, New Jersey. An unabsorbed antiserum to uterine fluid from a Day 5-pseudopregnant rabbit (used to detect uteroglobin: Beier, 1968) was kindly provided by Dr D. W. Bullock, Baylor University School of Medicine, Houston, Texas. Samples of rabbit antisera against the placental protein $\mathrm{SP}_{2}\left(\right.$ Bohn, 1972) and $\mathrm{hCG}_{\beta}$ were the gifts of Dr Vernon C. Stevens, Ohio State University, Columbus, Ohio. Rabbit antisera to pregnancy-associated plasma proteins (PAPPs), including antisera to PAPP-A and PAPP-C (Lin, Halbert, Kiefer \& Spellacy, 1974) and the pregnancy zone protein (Schoultz, 1974), were kindly supplied by Dr Seymour P. Halbert, University of Miami School of Medicine, Miami, Florida. Human alpha-fetoprotein (AFP) (Lan \& Leiukins, 1976) and the antiserum to AFP were supplied by the World Health Organization, through the efforts of Dr Jerry Mizejewski, New York State Department of Health.

Frozen samples of baboon decidua, obtained on Days 45-52 of pregnancy were supplied by Dr Gary T. Moore, Southwest Foundation for Research and Eduction, San Antonio, Texas. Rat decidual tissues were obtained from rats killed 4 days after the induction of decidualization in pseudopregnant animals, according to the method of Yoshinaga (1972). The baboon and rat tissues were homogenized in an approximately equal volume of cold $\left(4^{\circ} \mathrm{C}\right) 0.05 \mathrm{M}$-Tris- $\mathrm{HCl}$ buffer ( $\mathrm{pH} 7.4)$. The homogenates were clarified by centrifugation $(105000 \mathrm{~g}, 90 \mathrm{~min})$, and the clear supernates were stored at $-20^{\circ} \mathrm{C}$ until used. Samples for use as the source of uteroglobin were obtained by irrigation of the uterine lumen of Day 5-pseudopregnant rabbits with physiological saline solution $(9 \mathrm{~g} \mathrm{NaCl} / \mathrm{l})$. These samples were clarified by centrifugation at 850 $g$ for $30 \mathrm{~min}$ at $4^{\circ} \mathrm{C}$ and the supernates were stored at $-20^{\circ} \mathrm{C}$ until used.

The following human materials were procured with the co-operation of the patients and the physicians of the Albany Medical Center Hospital, Albany, New York. Decidua-rich tissue was obtained from women in early pregnancy (5-10 weeks) who accepted termination by menstrual induction. The tissues were processed to minimize contamination with fetal elements and blood (see Joshi et al., 1980). Term placentae were collected at the time of vaginal delivery, and portions of the fetal side were excised and processed to obtain placental extracts as previously described (Joshi et al., 1980). The extracts of several placentae were pooled. Blood samples were obtained from men, aged 20-45 years. The samples were clotted, centrifuged and combined to provide a pool of quality control male serum (QCMS). Unless stated otherwise, tissues and body fluids were stored at $-20^{\circ} \mathrm{C}$ until used.

\section{Immunological studies}

Two different preparations of antisera against antigens of decidua-rich tissues were used in tests for the presence of Antigens A and B. Antiserum 1 was produced in male rabbits against the unfractionated extract of the decidua-rich tissue, as described by Joshi et al. (1980) and was used only to study the subcellular localization of Antigens A and B in the decidua-rich tissues and to detect the presence of the two antigens in the protein fractions that were obtained during purification. Antiserum 2 was more potent and was raised in male rabbits against a partly purified preparation of Antigens $A$ and $B$ for use in all the characterization studies.

Before use, the two antisera were sequentially absorbed with immobilized proteins derived from QCMS and the pooled extract of placentae. These proteins were immobilized by coupling to $\mathrm{CNBr}$-activated Sepharose-4B by a method essentially similar to that described by Knauf \& Urbach (1977), except that in the present studies the coupling was carried out at $\mathrm{pH} 6.8$ rather than 8. Routinely, 1-ml portions of the antiserum were first absorbed with $30-50 \mathrm{mg}$ QCMS proteins and then with 30-50 mg placental proteins. Completion of the absorption was always checked by immunoelectrophoresis and immunodiffusion.

The immunoassays and polyacrylamide gel electrophoresis (PAGE) procedures were as previously described (Joshi et al., 1980). 


\section{Subcellular distribution of Antigens $A$ and $B$ in decidua-rich tissues}

The following cell fractionation steps were carried out at $4{ }^{\circ} \mathrm{C}$.

Several samples of decidua-rich tissues were thawed, pooled, and homogenized in about 2 volumes of $0.25 \mathrm{M}$-sucrose, $0.1 \mathrm{M}$-Tris- $\mathrm{HCl}, \mathrm{pH} 7.4$ (buffered sucrose solution). The homogenate was filtered through 4 layers of cheese cloth. The filtrate, hereafter referred to as a whole homogenate, was fractionated by differential centrifugation to obtain crude nuclei $(850 \mathrm{~g}$, $20 \mathrm{~min}$, sediment), heavy particulate fraction $(15000 \mathrm{~g}, 20 \mathrm{~min}$, sediment), light particulate fraction ( $105000 \mathrm{~g}, 90 \mathrm{~min}$, sediment), and cytosol (105000 $\mathrm{g}, 90 \mathrm{~min}$, supernatant). The crude nuclei and the particulate fractions were washed twice by suspension in buffered sucrose solution, followed by centrifugation at appropriate speeds. Finally, the washed sediments were suspended in $0.1 \mathrm{~m}$ phosphate buffer, $\mathrm{pH}$ 7. These suspensions and an aliquot of the cytosol were dialysed overnight against the same buffer, and adjusted to a protein concentration of 8-10 $\mathrm{mg} / \mathrm{ml}$ before treatment with sodium dodecyl sulphate (SDS) (1\% final concentration) and $\beta$-mercaptoethanol $\left(0.4 \%\right.$ final concentration) first at $100^{\circ} \mathrm{C}$ for $10 \mathrm{~min}$ and then at $65^{\circ} \mathrm{C}$ for 30 min as described by Lebond-Larouche, Morais, Nigam \& Karasaki (1975). After centrifugation $(105000 \mathrm{~g}, 90 \mathrm{~min})$ aliquots of the supernates were subjected to immunoelectrophoresis using Antiserum 1.

In some studies, tissue proteins were labelled with radioactive leucine by incubating fresh decidua-rich tissues (150-200 mg wet weight) in $1 \mathrm{ml}$ Eagle's MEM containing $10 \mu \mathrm{Ci}$ $\left[{ }^{3} \mathrm{H}\right]$ leucine for $2 \mathrm{~h}$ at $37^{\circ} \mathrm{C}$ under $95 \% \mathrm{O}_{2}-5 \% \mathrm{CO}_{2}$. After incubation, the tissues were washed in buffered sucrose solution and homogenized in the same buffer. Cell fractions were prepared from the homogenates and treated with SDS and $\beta$-mercaptoethanol, as described above. Duplicate aliquots of each of the cell fractions were subjected to PAGE in the presence of SDS (SDS-PAGE) on two different gels. After electrophoresis, one gel was sectioned into about 1.1 $\mathrm{mm}$ thick slices and radioactivity in the slices was determined by the method of Basch (1968). The other gel was used for the location of immunoreactive protein(s) by immunodiffusion against Antiserum 1. The details of these methods are given by Joshi et al. (1980).

In some studies, a glycoprotein fraction of cytosol of the decidua-rich tissues was prepared by Con A-Sepharose chromatography, as described by Joshi et al. (1980). This fraction was dialysed overnight at $4{ }^{\circ} \mathrm{C}$ against two changes of $0.1 \mathrm{M}$-Tris- $\mathrm{HCl}, \mathrm{pH} 7.4$, and concentrated to $8-10 \mathrm{mg} / \mathrm{ml}$ protein by ultrafiltration. Aliquots of all the fractions obtained by Con A-Sepharose chromatography were examined by immunodiffusion and immunoelectrophoresis, using Antiserum 1. Aliquots of the glycoprotein fraction were used for further purification of Antigens $A$ and $B$ by preparative PAGE and for characterization of the antigens.

For preparative PAGE, aliquots of the glycoprotein fraction, containing about $5 \mathrm{mg}$ protein, were added to sucrose (10\% w/v, final concentration) and bromophenol blue (tracking dye) and electrophoresed as described elsewhere (Joshi et al., 1980). After electrophoresis, two vertical gel strips (about $0.5 \mathrm{~cm}$ wide) were cut from the mid-section of each slab and the remaining slab pieces were wrapped in Cellophane and stored at $4^{\circ} \mathrm{C}$ in a humid chamber for later elution of the antigens. Antigens $\mathrm{A}$ and $\mathrm{B}$ in one of the gel strips were located by immunodiffusion on an agarose bed, as described elsewhere (Joshi et al., 1980). The remaining strip was used for rapid staining of the proteins with 1-aniline-8-naphthalene-sulphonate, as described by Hartman \& Udenfriend (1969). Preliminary studies had shown that Antigens A and B always migrated between the two major protein bands which had average relative mobilities $\left(R_{\mathrm{F}}\right) 0.54$ and 0.72 , respectively $\left(R_{\mathrm{F}}\right.$ of the tracking dye $\left.=1 \cdot 0\right)$. This was confirmed in each experiment by the immunodiffusion test. For elution of proteins, horizontal gel strips containing Antigens A and B (average $R_{\mathrm{F}}=0.68$ ) were sliced from the unstained slab. The gel was dispersed using a tissue press, and was collected in a $30-\mathrm{ml}$, screwcapped centrifuge tube. After addition of $0.01 \mathrm{M}$ phosphate buffer $(\mathrm{pH} 7)$ the tube was agitated end-to-end for about $24 \mathrm{~h}$ at $4^{\circ} \mathrm{C}$ to elute proteins. The eluate was recovered by centrifugation, and the elution step was repeated twice. 
The combined eluates were dialysed overnight at $4^{\circ} \mathrm{C}$ against phosphate buffer, and concentrated by ultrafiltration to a protein concentration of about $1 \mathrm{mg} / \mathrm{ml}$. Aliquots of this material, designated the PAGE fraction, were used for further analysis of protein components by SDS-PAGE on $10 \%$ acrylamide gels, as described above, and also tested against mono-specific antisera to known human proteins. Aliquots of the PAGE fraction were also used to immunize 4 male rabbits for the production of antisera, according to the protocol outlined elsewhere (Joshi et al., 1980). These antisera were absorbed with QCMS and placental proteins, and samples of the absorbed antisera which showed both Antigen A- and B-specificity were pooled. This pool of absorbed antiserum (Antiserum 2) was used in all the subsequent studies.

\section{Properties of Antigens $A$ and $B$}

Physical stability. Aliquots of the glycoprotein fraction of decidua-rich tissue cytosol, containing 2-4 mg protein/ml, were adjusted to a desired $\mathrm{pH}$ by the addition of $1 \mathrm{~N}-\mathrm{HCl}$ or 1 $\mathrm{N}-\mathrm{NaOH}$ and incubated at that $\mathrm{pH}$ for $2 \mathrm{~h}$ at room temperature $\left(22^{\circ} \mathrm{C}\right)$ with constant agitation. After incubation, the $\mathrm{pH}$ of the test solutions was readjusted to 7.4. Aliquots were also incubated at $40,50,60,70$ and $85^{\circ} \mathrm{C}$ for $30 \mathrm{~min}$ in a water bath. After incubation, the samples were cooled to room temperature $\left(22^{\circ} \mathrm{C}\right)$. Aliquots of the fractions exposed to different $\mathrm{pH}$ or temperature were clarified by centrifugation and tested immunoelectrophoretically against Antiserum 2.

Susceptibility to enzymes. Aliquots $(0.2 \mathrm{ml})$ of the glycoprotein fraction $(2 \mathrm{mg}$ protein $/ \mathrm{ml})$ were incubated in $0.1 \mathrm{M}$-Tris- $\mathrm{HCl}, \mathrm{pH} 7.4$ with trypsin, RNase, or DNase (final enzyme concentration, $1 \mathrm{mg} / \mathrm{ml}$ reaction mixture) for $4 \mathrm{~h}$ at $37^{\circ} \mathrm{C}$. After incubation, all the reaction mixtures, except those containing trypsin, were chilled in an iced-water bath. The mixtures containing trypsin were first supplemented with soybean trypsin inhibitor (final concentration 5 $\mathrm{mg} / \mathrm{ml}$ reaction mixture) and then chilled in the iced-water bath. Samples ( $2 \mathrm{mg}$ protein $/ \mathrm{ml})$ were also dialysed against $0.1 \mathrm{M}$-sodium acetate buffer, $\mathrm{pH} 5$, and aliquots $(0.1 \mathrm{ml})$ of the dialysed samples were incubated at $37^{\circ} \mathrm{C}$ in the presence of neuraminidase (final concentration 70 units/ $\mathrm{ml}$ ) for $18 \mathrm{~h}$ or with pepsin (final concentration $1 \mathrm{mg} / \mathrm{ml}$ ) for $2 \mathrm{~h}$. After incubation, the mixtures were dialysed overnight at $4^{\circ} \mathrm{C}$ against $0.1 \mathrm{M}$-Tris- $\mathrm{HCl}, \mathrm{pH} \mathrm{7.4}$. All the reaction mixtures were clarified by centrifugation for $10 \mathrm{~min}$ before immunoelectrophoresis.

Molecular weight. The glycoprotein fraction was placed on a precalibrated column $(90 \times$ $2.6 \mathrm{~cm}$ ) of Sephadex G-100 and Antigens A and B in the column fractions were detected by immunoelectrophoresis. In some studies, aliquots of the glycoprotein fraction and of proteins of known molecular weights were treated with SDS and $\beta$-mercaptoethanol as described above, and subjected to SDS-PAGE. After electrophoresis, antigens were detected by immunodiffusion using Antiserum 2.

Isoelectric point. Aliquots of the glycoprotein fraction were subjected to isoelectric focussing using LKB PAG plates in the LKB 2117 Multiphor with Model 2103 Power Supply (LKB Instruments Inc., Hicksville, New York). $\mathrm{H}_{3} \mathrm{PO}_{4}(1 \mathrm{M})$ and $\mathrm{NaOH}(1 \mathrm{M})$ were used as the anode and cathode electrode solutions, respectively. The power settings were identical to those recommended by the manufacturer. Two strips of approximately equal size containing the focussed proteins were cut out: one was used for the staining of protein bands by Coomassie brilliant blue R250, and the other was used for the location of Antigens A and B by diffusion of the protein fractions against Antiserum 2 on a solidified bed of $1 \%$ agarose in veronal buffer, as described by Joshi et al. (1980).

Identity with other proteins. Antiserum 2 to decidua-rich tissue was reacted with a purified preparation of known plasma or pregnancy proteins (e.g. transferrin, ceruloplasmin, alpha1 -antitrypsin, ferritin, uteroglobin and $a$-fetoprotein) or aliquots of the PAGE fraction of 
decidua-rich tissue were allowed to react with monospecific antisera against the known proteins. In control studies, the known proteins were individually identified by their cross-reaction with their respective antisera. Identity with the $\beta$ unit of hCG was studied by determining the ability of the PAGE fraction to compete with ${ }^{125} \mathrm{I}$-labelled $\beta \mathrm{hCG}$ in its binding to the antiserum to $\beta$ hCG, or of the Antiserum 2 to decidua-rich tissue to bind the tracer amount of ${ }^{125}$ I-labelled $\beta$ hCG. Such binding studies were carried out according to the radioimmunoassay procedure described by Vaitukaitis, Braunstein \& Ross (1972). Identity with PAPPs, PAPP-A, and PAPP-C was studied by cross-reacting the PAGE fraction with anti-PAPP-A, -PAPP-C, or PAPPs, according to the sensitive two-dimensional immunodiffusion method proposed by Gall \& Halbert (1972). In control studies, serum from women in the third trimester of pregnancy was used as the source of PAPP-A and -C. In addition, an aliquot of the PAGE fraction of the decidua-rich tissue was subjected to immunoelectrophoresis, using the antiserum to the placental protein, $\mathrm{SP}_{1}$, in an effort to detect $\mathrm{SP}_{1}$ in the PAGE fraction. In control studies, anti-SP $\mathbf{S P}_{1}$ was reacted with an extract of the term placenta that served as the source of $\mathrm{SP}_{1}$. In addition, Antiserum 2 was reacted with uterine fluid from Day 5-pseudopregnant rabbits, and rat antiserum to these uterine fluids was reacted with the decidua-rich tissue PAGE fraction to compare Antigens A and B with uteroglobin. Finally, aliquots of Antiserum 2 were allowed to react with extracts of baboon or rat decidua to study the species specificity of the human antigens.

Protein estimation. The colorimetric method of Lowry, Rosebrough, Farr \& Randall (1951) was used to determine protein content of the test samples.

Materials. Those used were as follows: Concanavalin A bound to Sepharose-4B (Con A-Sepharose); Sephadex G-100 (40-120 $\mu \mathrm{m}$ particle size); CNBr-activated Sepharose-4B; ribonuclease A; chymotrypsinogen A; ovalbumin (all from Pharmacia Fine Chemicals, Piscataway, New Jersey); rabbit serum albumin (Nutritional Biochemicals, Cleveland, Ohio); premade Standard ORTEC Gradipore acrylamide gel slabs (4-26\%) and the acrylamide kit (Ortec Incorporated, Oak Ridge, Tennessee); ceruloplasmin; ferritin; transferrin; deoxyribonuclease (DNase, Type 1, from bovine pancreas); trypsin (Type I, from bovine pancreas); trypsin inhibitor (Type I-S, from soybean); ribonuclease A (RNase, Type I-A from bovine pancreas) (all from Sigma Chemical Co., St. Louis, Missouri); neuraminidase (from Clostridium perfringens); pepsin A (from bovine stomach) (both from Worthington Biochemical Corporation, Freehold, New Jersey); Eagle's minimal essential medium, without leucine (Eagle's MEM) (Grand Island Biological Co., Grand Island, New Jersey); [4,5- ${ }^{3}$ H]leucine, sp. act. 52 $\mathrm{Ci} / \mathrm{mmol}$ (Amersham Corporation, Arlington Heights, Illinois); $\beta$-subunit of human chorionic gonadotrophin (HCG $\beta-C R 115 B$ :NIAMDD, Bethesda, Maryland); agarose (Marine Colloids, Inc., Rockland, Maryland); 1-anilino-8-naphthalene-sulphonate (magnesium salt) (Eastman Organic Chemicals, Rochester, New York); polyacrylamide gels containing ampholines; LKB PAG plates (pH range 3.5-9.5) (LKB Instruments, Inc., Hicksville, New York).

\section{Results}

\section{Subcellular distribution of Antigens $A$ and $B$}

As shown in Text-fig. 1, the SDS-dissociated proteins of all except the light particulate fraction reacted with Antiserum 1 to form a single diffuse precipitin line. Cytosol aliquots which were not treated with SDS reacted to form two precipitin lines corresponding to Antigens A and B.

In subsequent studies, proteins of the decidua-rich tissues which were labelled with $\left[{ }^{3} \mathrm{H}\right]$ leucine were resolved by SDS-PAGE and reacted with Antiserum 1. As shown in Text-fig. 


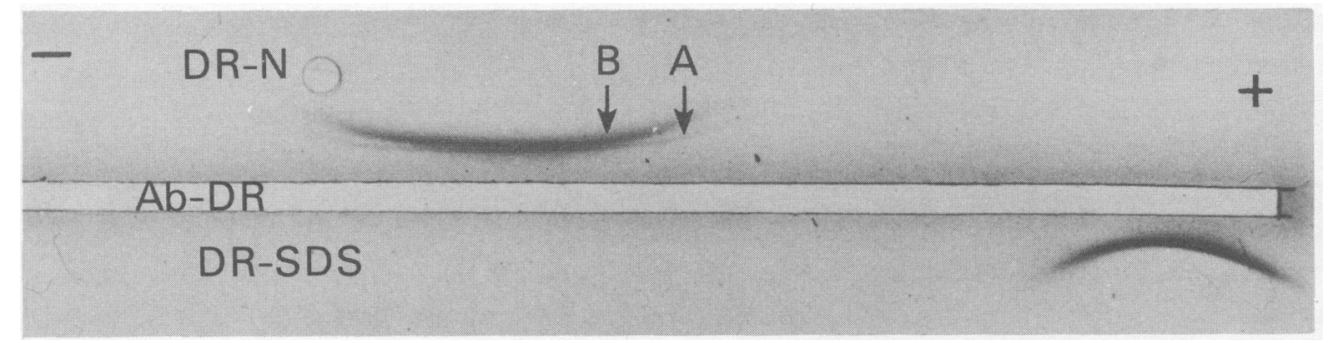

Text-fig. 1. Effect of sodium dodecyl sulphate treatment (SDS) on immunological reactivity of decidual tissue cytosol, as studied by immunoelectrophoresis. DR-N: native cytosol of decidua-rich tissue (DR). DR-SDS: DR cytosol treated with SDS. Ab-DR: rabbit anti-DR exhaustively absorbed with extract of term placenta. A,B: the immunoprecipitate lines of Antigens $\mathbf{A}$ and $\mathbf{B}$.

2 , electrophoretic fractionation of the radiolabelled proteins of the heavy particulate fraction and the cytosol yielded at least 3 radioactivity peaks. The protein of one peak $\left(R_{\mathrm{F}}\right.$ about 0.5$)$ reacted with the formation of only one diffuse precipitin line. Similar radioactivity profiles were obtained when leucine-labelled proteins of the light particulate fraction were electrophoresed on

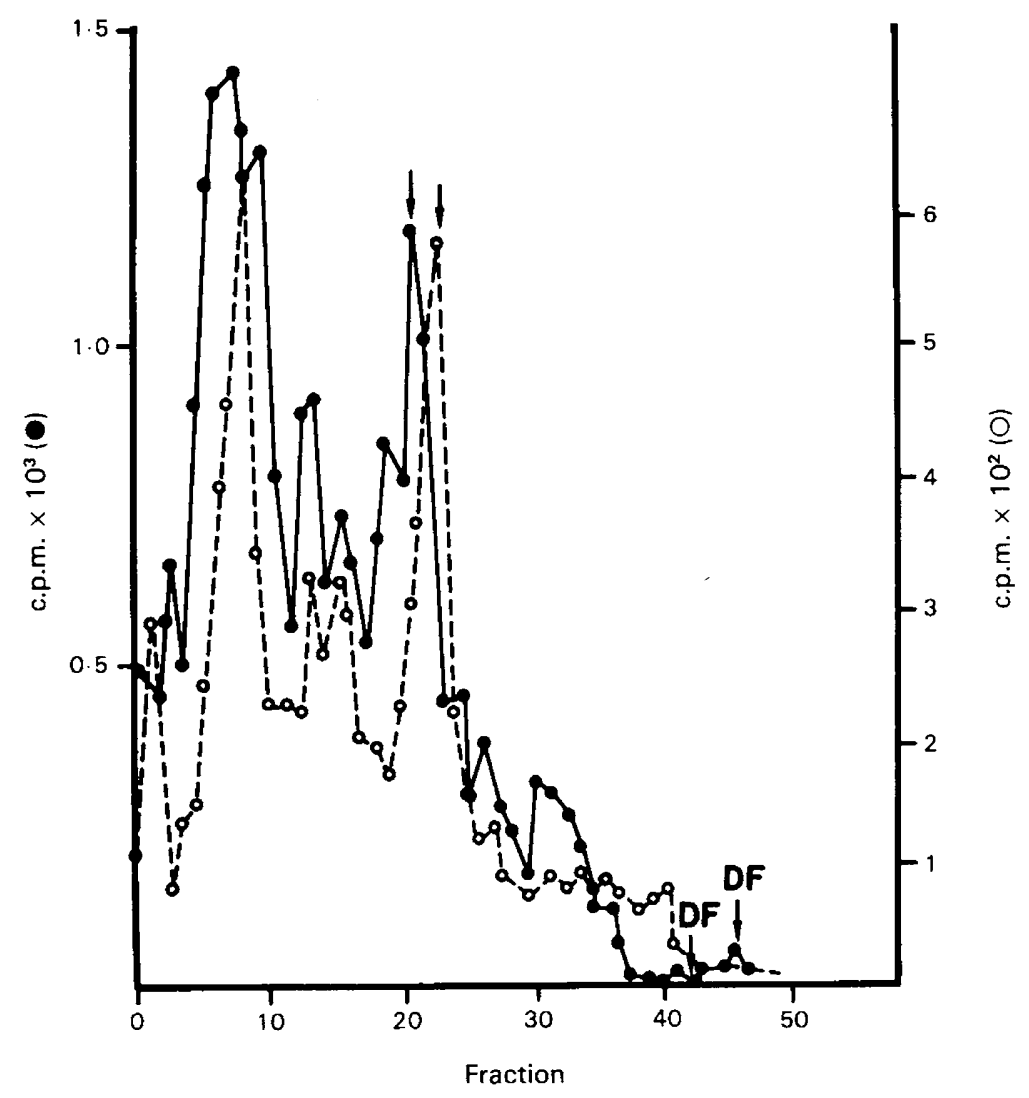

Text-fig. 2. Fractionation of the leucine-labelled proteins of cytosol $(\mathrm{O}---\mathrm{O})$ and the heavy particulate fraction (-O) of decidua-rich tissue on two separate $10 \%$ acrylamide gels containing SDS. The arrows indicate the fractions containing antigenic proteins, as determined separately by an immunodiffusion test using the absorbed antiserum to decidua-rich tissue. DF $=$ dye front. 
SDS-containing gels, although no immunoreactive protein(s) could be demonstrated in any of the radioactivity peaks (results not shown).

Protein analysis of the fractions indicated that more than $60 \%$ of the total protein in the homogenate of the decidua-rich tissues was recovered in the cytosol fraction whereas the remaining protein was evenly distributed between the crude nuclear and heavy particulate fractions.

Fractionation of a cytosol aliquot ( $\sim 300 \mathrm{mg}$ protein) by Con A-Sepharose chromatography showed that Antigens A and B were present only in the glycoprotein fraction which bound to Con A-Sepharose and which contained about $7 \%$ of the total cytosol protein. A further enrichment of the two antigens was obtained by subjecting the glycoprotein fraction to PAGE. This procedure yielded an Antigen A- and B-rich fraction which contained approximately one-tenth the amount of glycoprotein used for PAGE. However, this PAGE fraction was not homogeneous. Further resolution by SDS-PAGE revealed that it contained at least 10 minor protein bands and one major protein band. The latter reacted with Antiserum 1 to form one highly diffuse precipitin line. Immunodiffusion studies with monospecific antisera against known plasma proteins demonstrated the presence of transferrin, alpha-1-antitrypsin and ceruloplasmin. The PAGE fraction evoked a strong antibody response in all 4 rabbits that were immunized with this material. Examination of these second generation antisera, after absorption with QCMS or placental extracts, showed that they were qualitatively similar to those of the first generation antisera with respect to their reactivity with tissue extracts and sera. They reacted
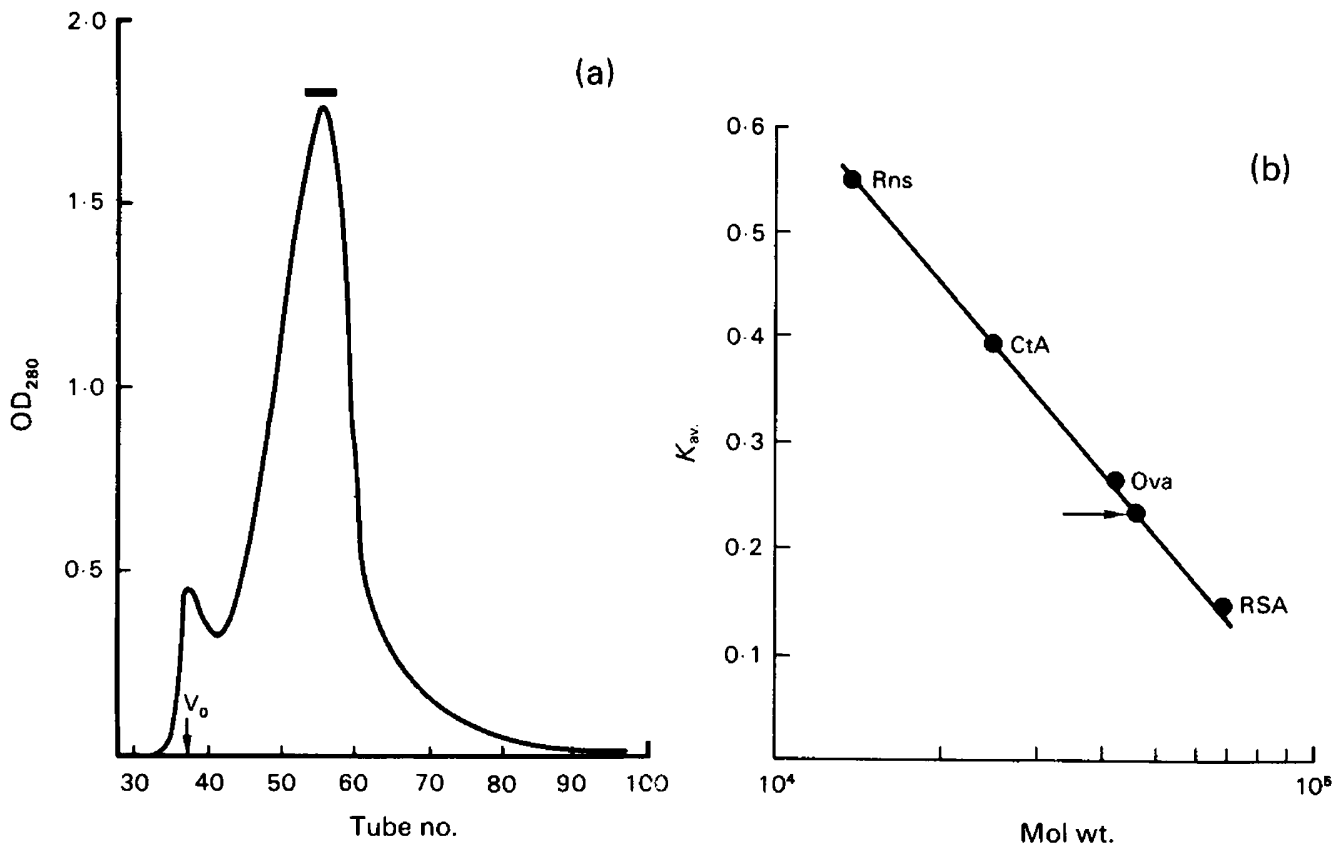

Text-fig. 3. Sephadex G-100 filtration of the glycoprotein fraction of decidua-rich tissue showing (a) the elution profile and (b) molecular weight estimation by comparison with standard purified proteins. In (a) a sample $(3.4 \mathrm{ml})$ of glycoprotein fraction $(15 \mathrm{mg}$ protein) in $0.1 \mathrm{M}$-Tris- $\mathrm{HCl}$, $\mathrm{pH} 7.4$, containing $0.5 \mathrm{M}-\mathrm{NaCl}$ was applied onto a column $(2.6 \times 88 \mathrm{~cm})$ and the eluates were collected ( $4 \mathrm{ml} /$ tube) at a flow rate of $27 \mathrm{ml} / \mathrm{h}$. The tubes containing Antigens A and B are marked by the horizontal bar. $\mathrm{V}_{0}=$ void volume. In (b), Rns = ribonuclease, CtA $=$ chymotrypsinogen $\mathrm{A}$, Ova = ovalbumin, RSA = rabbit serum albumin. The arrow shows Antigens A and B with the apparent molecular weight of 48000 . 
with decidua-rich tissues but not with extract of term placentae, or QCMS. They were therefore combined and this pooled antiserum (No. 2) was used in all subsequent studies.

\section{Characterization of Antigens $A$ and $B$}

Neither temperature $\left(40,50,60,70,85^{\circ} \mathrm{C}\right)$ nor $\mathrm{pH}(2,4,6,8,10,12)$ affected the reactivity of Antigens A and B to Antiserum 2. Exposure to pepsin (pH 5.0, incubation $2 \mathrm{~h}$ ), RNase or

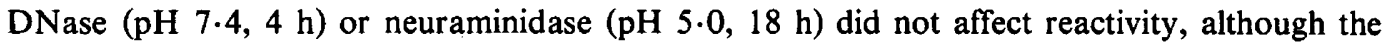
neuraminidase treatment altered the electrophoretic mobility of the antigens. Treatment with

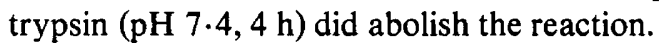

Gel filtration on a Sephadex G-100 column resolved the glycoproteins of the decidua-rich tissue into a minor protein fraction, which appeared in the void volume, and a major fraction, which was slightly retarded (Text-fig. 3a) and contained Antigens A and B. The apparent molecular weights of the antigens, as determined by gel filtration, were similar (approximately 48000 ) (Text-fig. 3b). However, the dissociation of Antigens A and B by SDS under reducing conditions yielded only one immunoreactive component with an approximate molecular weight of 27000 (Text-fig. 4).

The isoelectric point of both Antigens A and B was about 4.9. The results of the studies that were undertaken to identify Antigens $A$ and $B$ with other known plasma proteins were uniformly negative, although in the control studies all the plasma or pregnancy-associated proteins could be readily detected by the appropriate tests.

In immunoelectrophoretic and immunodiffusion tests, Antiserum 2 did not react with the cytosols of rat or baboon decidua.

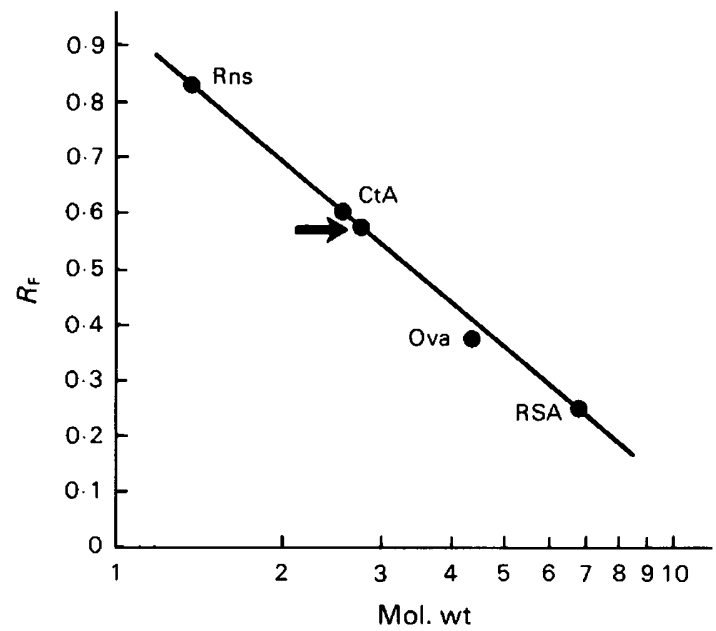

Text-fig. 4. Molecular weight determination by comparison of relative mobility with standard purified proteins by SDS-gel electrophoresis. $\mathrm{Rns}=$ ribonuclease, $\mathrm{CtA}=$ chymotrypsinogen $\mathrm{A}$, Ova $=$ ovalbumin, $R S A=$ rabbit serum albumin. The arrow shows the endometrial antigen with the apparent molecular weight of 27000 .

\section{Discussion}

We have previously demonstrated that explants of pregnancy and non-pregnancy human endometria incorporate radioactive leucine into soluble tissue proteins which are precipitated by absorbed antiserum to decidual tissue, suggesting that Antigens $\mathrm{A}$ and $\mathrm{B}$ are synthesized within 
the human endometrium and not sequestered from the peripheral blood. This observation has been confirmed in the present study, which, in addition, shows that some of the antigenic activity is associated with the cell membranes which are sedimented with the crude nuclei and the heavy particulate fraction. Studies are in progress to determine whether the two antigens are integral components of the plasma membranes.

In the present study, the simultaneous presence of both Antigens A and B could not be convincingly demonstrated in the particulate fraction of the decidua-rich tissue. The reaction of the SDS-treated particulate fractions or SDS-treated tissue cytosol with the antiserum against the decidua-rich tissue cytosol always produced one rather than two precipitin lines, indicating that Antigens A and B are two different forms of one antigenic protein. In subsequent studies the cytosol proteins were subjected to protein fractionation methods to determine whether Antigens $A$ and $B$ are chemically two different proteins and, if so, whether they could be separated from each other. Attempts were made to fractionate them by ion-exchange chromatography using DEAE-Sephadex, DEAE-cellulose or hydroxylapatite, and by step-wise salting-out precipitation with ammonium sulphate. However, these methods did not resolve the two antigens or provide adequate enrichment. Isoelectric focussing, gel filtration and Con A-Sepharose chromatography followed by PAGE also failed to separate them, suggesting that the two antigens are chemically similar. All other studies (exposure of antigens to different $\mathrm{pH}$, temperature, and enzymes) used to characterize the antigens gave similar results for both forms. These similarities in properties of the antigens, and the finding that only one antigenic component is detected in the membranous fractions of the decidua-rich tissues, strongly suggest that Antigens A and B represent two different forms of only one protein with an approximate molecular weight of 48000 . Furthermore this protein may consist of two subunits, each having a molecular weight of approximately 27000 . The effect of trypsin indicates that the antigenic determinants are located in the protein rather than in the terminal sialic acid residues. It is possible that the oxidation of sulphydryl groups during antigen purification, storage, freezing and thawing and even during diffusion through an agarose gel might produce or rearrange intramolecular disulphide bonds to effect such a configuration change and to produce two precipitin patterns corresponding to Antigens A and B. Furthermore, the two forms of antigen may evoke the formation of two different populations of antibodies in rabbits. These possibilities are being examined.

Several normal plasma proteins, tissue antigens, enzymes and polypetide hormones are known to be elevated during pregnancy or during hormonal contraception. Therefore, it was of importance to know whether Antigens A and B were related to any known pregnancy-associated plasma or tissue protein. However, attempts to identify the human endometrial antigens with other such proteins were consistently negative. The antigens also appear to be species specific. Shapiro \& Forbes (1978) have demonstrated that the exposure of the human endometrium to progestagens in vivo and in vitro stimulates the incorporation of radioactive leucine into a specific protein of molecular weight 51500 . Sutcliffe, Brock, Nicholson \& Dunn (1978) have shown the presence of a uterine protein, designated alphauterine protein or AUP, in human amniotic fluid; this AUP appears to be a dimer with units of molecular weight 25000 . Whether Antigens A and B are related to the human uterine proteins described by Shapiro \& Forbes (1978) and Sutcliffe et al. (1978) cannot be determined by the present study. The ultimate purification and characterization of Antigens A and B are of considerable importance since these glycoproteins represent markers of progestagen action in the human endometrium, and could regulate pre- or post-implantation development of the embryo.

We thank Professor Herbert Jacobson for critical review of the manuscript. The study was supported by the Ford Foundation (grant 680-0900) and the National Institute of Child Health and Human Development (grant HD-09622). 


\section{References}

Basch, R.S. (1968) An improved method for counting tritium and carbon-14 in acrylamide gels. Analyt. Biochem. 26, 184-188.

Bejer, H.M. (1968) Uteroglobin-a hormone sensitive endometrial protein involved in blastocyst development. Biochim. Biophys. Acta 160, 289-291.

Bohn, H. (1972) Isolation and characterization of pregnancy-specific $\beta_{1}$-glycoprotein. Blut 24, 292302.

Gall, S.A. \& Halbert, S.P. (1972) Antigenic constituents in pregnancy plasma which are undetectable in normal, non-pregnant female or male plasma. Int. Arch. Allergy Appl. Immunol. 42, 503-515.

Hartman, B.K. \& Udenfriend, S. (1969) A method for immediate visualization of proteins in acrylamide gels and its use for preparation of antibodies to enzymes. Analyt. Biochem. 30, 391-394.

Joshi, S.G., Ebert, K.M. \& Swartz, D. (1980) Detection and synthesis of progestagen-dependent proteins of the human endometrium. J. Reprod. Fert. 59, 273-285.

Knauf, S. \& Urbach, G.I. (1977) Purification of human ovarian tumor-associated antigen and demonstration of circulating tumor antigen in patients with advanced ovarian malignancy. Am. J. Obstet. Gynec. 127, 705-710.

Lan, H.L. \& Leiukins, S.E. (1976) Alpha-fetoprotein. Am. J. Obstet. Gynec. 124, 534-554.

Lebond-Larouche, L., Morais, R., Nigam, B.V. \&
Karasaki, S. (1975) A comparative study of carbohydrate content, protein, glycoprotein, and ganglioside patterns of Novikoff ascitis-hepatoma and normal liver. Archs Biochem. Biophys. 167, 1-12.

Lin, T., Halbert, S.P., Kiefer, D. \& Spellacy, W.N. (1974) Characterization of four pregnancy-associated plama proteins. Am. J. Obstet. Gynec. 118 , 223-236.

Lowry, O.H., Rosebrough, N.J., Far,, A.L. \& Randall, R.J. (1951) Protein measurement with the Folin phenol reagent. J. biol. Chem. 193, 265-275.

Schoultz, B. (1974) A quantitative study of the pregnancy zone protein in the sera of pregnant and puerperal women. Am. J. Obstet. Gynec. 119, $792-797$.

Shapiro, S. S. \& Forbes, S.H. (1978) Alterations in human endometrial protein synthesis during the menstrual cycle and in progesterone-stimulated organ culture. Fert. Steril. 30, 175-180.

Sutcliffe, R.G., Brock, D.J.H., Nicholson, L.V.B. \& Dunn, E. (1978) Fetal- and uterine-specific antigens in human amniotic fluid. J. Reprod. Fert. 54, 85-90.

Vaitukaitis, J.L., Braunstein, G.D. \& Ross, G.T. (1972) A radioimmunoassay which specifically measures human chorionic gonadotropin in the presence of human lutenizing hormone. Am. J. Obstet. Gynec. 113, 751-757.

Yoshinaga, K. (1972) Rabbit antiserum to rat deciduoma. Biol. Reprod. 6, 51-57.

Received 24 July 1979 